\title{
The Effect of Abdominal Fat Distribution on Leptin in Regular Exercisers 規律運動者腹部脂肪分佈與瘦體蛋白的影響
}

\author{
Chin Hsing HSU $^{1}$ Te Hung TSAO $^{2}$ \\ Shiou Tau SHU $^{2}$ Chang Bin YANG $^{3}$ \\ ${ }^{1}$ Recreation Sports \& Health Promotion Department \\ National Pingtung University of Science and Technology, TAIWAN \\ ${ }^{2}$ Division of Physical, Health and Service Learning Center, \\ National Sun Yat-sen University, TAIWAN \\ ${ }^{3}$ Department of Physical Education and Kinesiology, \\ National Dong Hwa University, TAIWAN
}

\author{
徐錦興 ${ }^{1}$ 曹德弘 ${ }^{2}$

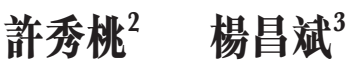 \\ '台灣國立屏東科技大學休閒運動保健系 \\ 2台灣國立中山大學體育健康與服務教育組 \\ ${ }^{3}$ 台灣國立東華大學體育與運動科學系
}

\begin{abstract}
Purpose: In this study, we examined different regular exercisers' abdominal fat distribution and relationships between serum leptin levels and the abdominal fat distribution. In addition, determining whether the waist (WC) and hip circumferences (HC) were related to the abdominal fat distribution in regular exercisers was another goal of this study. Method: runners (R, $\mathrm{n}=12$ ) and swimmers $(\mathrm{S}, \mathrm{n}=9)$, who exercised at least 5 times/week for 30 minutes/time and for at least 3 years, participated in this study. In addition, sedentary individuals $(n=10)$, who exercised less than once/week and $>30$ minutes/per time, served as a control group (C). All participants had a magnetic resonance imaging (MRI) scan for the abdominal fat distribution, blood analysis for leptin and measurements of WC, HC and body-mass index (BMI). Results: On the basis of BMImatching, the $R$ group's abdominal visceral fat $(0.4 \pm 0.3 \mathrm{~L})$ was less than those of the $\mathrm{S}$ and $\mathrm{C}$ groups $(0.8 \pm 0.2 \mathrm{~L}$ and $0.9 \pm 0.3 \mathrm{~L}$, respectively), and no significant differences in abdominal subcutaneous fat or serum leptin levels were evident among these three groups. The relationships between serum leptin and the abdominal fat distribution differed in the $\mathrm{R}$ and $\mathrm{S}$ groups. In the measurement of body circumference and abdominal fat distribution, WC was significantly related to abdominal subcutaneous fat among the three groups. Conclusions: Taking regular exercise can cause a decrease in the visceral fat accumulation, especially for people who are regular runners. The WC can be used to predict the abdominal subcutaneous fat of exercisers. Further studies are required in the future to determine the contribution of abdominal fat to serum leptin in exercisers.
\end{abstract}

Key words: magnetic resonance imaging, abdominal visceral fat, abdominal subcutaneous fat, adipose tissue 


\section{摘要}

本研究目的：探討不同規律運動者腹部脂肪分佈與瘦體蛋白的關係。再者, 規律運動者腹部脂肪分佈與體圍 (腰圍與臀圍) 是否有關, 是本研究另一目的。方法 : 分別有 12 位與 9 位長期從事慢跑與游泳的受試者參與, 其從事該項運動至少 3 年, 每週至少 5 次, 每次至少 30 分鐘以上。另外有 10 位坐式生活者 (每週至多一次, 每次不超過30分鐘的身體活動) 作為控制組。所有受試者 都接受磁共振造影掃瞄腹部脂肪分佈, 隔夜禁食之血液中瘦體蛋白濃度分析與腰圍與臀圍的測量。結果 : 在三組的受試者身體質 量指數未達顯著差異, 慢跑組的腹部內臟脂肪體積顯著少於游泳組與控制組。但三組之間的腹部皮下脂肪體積與血液中瘦體蛋白 未達顯著差異。再者, 慢跑組與游泳組的瘦體蛋白與腹部脂肪分佈的關係呈現不同。在體圍與腹部脂肪分佈, 三組的腰圍與腹部 皮下脂肪體積有顯著相關。結論: 從事規律的運動有助於減少腹部內藏脂肪堆積, 特別是從事規律慢跑者。腰圍可用來預測運動 者的腹部皮下脂肪。然而對於規律運動者腹部脂肪與瘦體蛋白的關係仍須未來更多研究進行探討。

\section{關鍵詞 : 磁共振造影, 腹部內臟脂肪, 腹部皮下脂肪, 脂肪組織}

\section{Introduction}

It was recently well established that the accumulation of abdominal visceral fat is associated with metabolic and cardiovascular diseases, for example diabetes, hyperglycerides, heart diseases and stroke (Pouliot et al. 1994; Tarui, Tokunaga, Fujioka, and Matsuzawa, 1991). In order to decrease body fat accumulation and the risks of those diseases, regular exercise is one of the important preventive methods. According to the American College of Sports Medicine (ACSM), exercising $\geq 30 \mathrm{~min}$ or more each time at moderate intensity at least 5 days/week or exercising $20 \mathrm{~min}$ at higher intensity at least 3 days/ week is beneficial for weight management and diseases prevention (Haskell et al. 2007). However, each sport has its own unique characteristics. As a result, habitually engaging in one specific sport for a long time may produce a different body composition, e g, lower body fat, higher bone mineral density, and lean mass (Pratley, Hagberg, Rogus, \& Goldberg, 1995; Sugawara et al., 2002) when compared to sedentary people. However, little is known about whether regular long-term exercise influences body fat distribution patterns, for example the abdominal fat distribution or truncal fat, although exercise is known to help lower the fat mass.

In addition to storing energy, body fat is a tissue that secretes hormones, for example leptin and adiponectin (Berggren, Hulver, \& Houmard, 2005). As far as leptin's function is concerned, leptin signals and cooperates with the hypothalamus to reduce food intake and control energy metabolism and body weight (Campfield, Smith, Guisez, Devos, \& Burn, 1995; Halaas et al., 1995; Pelleymounter et al., 1995). Studies showed (Considine et al., 1996; Nagura et al., 2004) that leptin is significantly related to the percent body fat and body mass index (BMI), even in competitive or strenuous athletes or exercisers who had smaller percent body fat (Hickey et al. 1996; Leal-Cerro et al. 1998). Other studies (Masuzaki et al. 1995; Ronnemaa, Karonen, Rissanen, Koskenvuo, \& Koivisto, 1996) showed that the relationships between adipose tissue and leptin differed due to the position of the fat distribution, and different body fat parts might variably contribute to leptin secretion. However, those studies did not involve athletes or regular exercisers.

Additionally, many studies (Kim et al., 2004; Pouliot et al., 1994; Roopakala et al., 2009) reported that a significant relationship exists between the abdominal fat distribution and body circumference, e.g., waist circumference (WC) and hip girth; these indices can be predictors of the abdominal fat distribution. But, those studies selected people from the general population, or overweight or obese persons, as participants. Therefore, the association between abdominal fat distribution and body circumference in habitual exercisers has scarcely been discussed.

On the basis of the above-mentioned problems, the goal of this study was twofold: to determine (1) the abdominal fat distribution in long-term regular exercisers and sedentary people and its relationships with leptin, and (2) the association between the fat distribution and body circumference of exercisers. It was hypothesized that the abdominal fat distribution would be associated with leptin and body circumference in exercise participants in this study. 


\section{Methods}

\section{Subjects}

The ethics committee of the local hygiene and health bureau approved this study. Thirty-seven males were enrolled in this study after each participant understood the procedures of the research and provided a signed consent form. Exercise groups included two different sports. One group contained runners $(\mathrm{n}=15)$ and the other group contained swimmers ( $\mathrm{n}=12)$. The control (C) group $(\mathrm{n}=10)$ consisted of 11 age-matched sedentary persons (who exercised at most one time per week, each time fro < 30 minutes). Runners (R) and swimmers (S) maintained at least 30-minutes/each times, 5 days/week for more than 3 years. In addition to investigating regular exercise habits by a questionnaire, all participants' cardiopulmonary fitness, in terms of maximal oxygen consumption $\left(\mathrm{VO}_{2} \mathrm{max}\right)$, was determined by Bruce's treadmill protocols (ACSM, 2006) (SensorMed VU MAX29,Yorba Linda, CA, USA). The value of $\dot{\mathrm{VO}}_{2} \max$ was considered if at least two of the following criteria were met: 1) an $\mathrm{RQ}$ of $>1.05$ with a $\mathrm{VO}_{2}$ plateau despite an increase in exercise intensity (speed or grade), 2) a heart rate within 10 beats/min of the aged-predicted maximum (Vantage XL Polar System, Port Washington, NY, USA), and 3) a rating of perceived exertion of $>17$ on the Borg scale (Borg, 1998).

\section{Magnetic Resonance Imaging}

The abdominal fat distribution, including visceral adipose tissue and subcutaneous adipose tissue, was measured in the Department of Diagnostic Radiology at Ho-Shin Cancer Research Hospital using a magnetic resonance imaging system (General Electric Medical System, USA). Subjects were scanned at $8 \mathrm{~mm}$, with a 2$\mathrm{mm}$ gap in the supine position from the diaphragm to the bottom of the pelvis. The rapid T1-weighted images were used to show good contrast between adipose and non-adipose tissues. Details of the MRI imaging were as follows: a repetition time of $450 \mathrm{~ms}$ and echo time of $12 \mathrm{~ms}$, a field of view of $400 \sim 800 \mathrm{~mm}$, and a matrix of $192 \times 256$. The volume $(\mathrm{L})$ of abdominal subcutaneous and visceral fat was calculated from a formula of a study by Ross et al. (1994).
Anthropometric Measurements and Blood Analysis

Before fasting-blood sample collection, the percent body fat and waist (WC) and hip (HC) circumference measurements were completed in each participant. The body density of all participants was determined by skinfold thickness gauged at four sites, the biceps, triceps, and subscapular and suprailiac regions (Durnin \& Womersley, 1974), using Harpenden calipers (John Bull, St. Alban, UK), and body density was converted to percent body fat using Siri's (1961) equation. A non-stretchable 0.5-cm-wide tape measure was used for $\mathrm{WC}$ and $\mathrm{HC}$ measurements. The WC was measured midway between the inferior margin of the last rib and the crest of the ileum in the horizontal plane at the end of normal expiration. The $\mathrm{HC}$ was measured around the pelvis at the point of maximal protrusion of the buttocks. The circumference was measured to the nearest $0.1 \mathrm{~cm}$. If the variation between these two measurements was greater than $1 \mathrm{~cm}$, a third measurement was taken and the mean was calculated using the two closest measurements. The above measurements were performed by the same experienced person. Participants' blood samples were taken after $12 \mathrm{~h}$ of overnight fasting. The levels of leptin were measured by an enzyme-linked immunosorbent assay (ELISA) using a kit of Diagnostic Systems Laboratories (St. Charles, MO, USA). The sensitivity for leptin was $0.05 \mathrm{ng} / \mathrm{ml}$. The intra-assay and inter-assay coefficients for leptin were both $<5.0 \%$.

\section{Statistical Analysis}

The statistical analyses for different variables among the three groups were performed by applying oneway analysis of variance (ANOVA). Turkey's post hoc tests were performed on all significant mean differences. Statistical significance was set to $\mathrm{p}<0.05$. Correlation analyses were performed using Pearson's product-moment correlation in each group. All data were analyzed with SPSS 11.0 version statistical package (SPSS Inc., Chicago, IL) and are expressed as the mean $\pm \mathrm{SD}$. 


\section{Results}

The subjects' age, physical characteristics, and maximal oxygen consumption of the three groups are displayed in Table 1. Age and BMI showed no significant difference among the three groups as per the experimental design. In addition, the percent body fat also showed no significant difference among these groups, although that of group $\mathrm{C}$ was higher than those of the other groups. VO2max values of the $\mathrm{R}$ and $\mathrm{S}$ groups were significantly higher than that of group $\mathrm{C}$, but, there was no significant difference between groups $\mathrm{R}$ and $\mathrm{S}$ for this variable.

Although there were no significant differences in the BMI and percent body fat, a significant difference was found in the abdominal visceral fat volume and the $\mathrm{R}$ group's visceral fat volume was significantly less than those of the S and C groups by Turkey's tests. The abdominal subcutaneous fat volume, however, did not show a significant difference in among the three groups.

Table 1. Each Groups' Body Composition, Fat Distribution and Blood Variables.

\begin{tabular}{|c|c|c|c|c|c|c|c|c|c|}
\hline \multirow[b]{2}{*}{ Age (years) } & \multicolumn{3}{|c|}{$\mathrm{R}(\mathrm{n}=12)$} & \multicolumn{3}{|c|}{$S(n=9)$} & \multicolumn{3}{|c|}{$C(n=10)$} \\
\hline & 31.3 & \pm & 10.8 & 37.1 & \pm & 8.7 & 33.1 & \pm & 6.8 \\
\hline $\mathrm{BMI}\left(\mathrm{kg} / \mathrm{m}^{2}\right)$ & 22.0 & \pm & 1.4 & 22.3 & \pm & 1.1 & 22.1 & \pm & 0.7 \\
\hline Percent body fat ( $\%$ ) & 9.3 & \pm & 2.9 & 11.9 & \pm & 2.4 & 12.1 & \pm & 3.2 \\
\hline $\operatorname{AVF}(\mathrm{L})$ & 0.4 & \pm & $0.3^{*}$ & 0.8 & \pm & 0.2 & 0.9 & \pm & 0.3 \\
\hline ASF (L) & 1.7 & \pm & 0.9 & 2.5 & \pm & 0.9 & 2.4 & \pm & 0.9 \\
\hline Leptin $(\mu \mathrm{g} / \mathrm{L})$ & 1.6 & \pm & 0.6 & 2.4 & \pm & 0.8 & 2.4 & \pm & 1.9 \\
\hline $\mathrm{VO}$ max & 52 & \pm & 3.9 & 50 & \pm & 3.2 & 41.7 & \pm & 4.3 \\
\hline
\end{tabular}

*means $\mathrm{p}<0.05 \mathrm{R}$, runner group; S, swimmer group; C, control group; BMI, body mass index; AVF, abdominal visceral fat; ASF, abdominal subcutaneous fat.

There were different relationships between serum leptin levels and abdominal fat distributions in the three groups. In group $\mathrm{R}$, serum leptin levels were significantly related to abdominal subcutaneous fat $(\mathrm{r}=0.83, \mathrm{p}<0.05)$ and visceral fat $(\mathrm{r}=0.87, \mathrm{p}<0.05)$. However, there were no significant associations between serum leptin levels and abdominal subcutaneous fat or visceral fat in group S. In addition, a significant relationship existed between serum leptin levels and abdominal subcutaneous fat $(\mathrm{r}=0.87$, $\mathrm{p}<0.05)$ in the group $\mathrm{C}$.

Relationships between body circumferences and the abdominal fat distribution in these three groups were also analyzed. Only the WC was significantly related to abdominal visceral fat in group R. However, the WC was significantly related to abdominal subcutaneous fat across the three groups $(r=0.88,0.83$ and 0.91 for the $R, S$, and $\mathrm{C}$ groups, respectively, $\mathrm{p}<0.05$ ). On the other hand, no significant association was found between the $\mathrm{HC}$ and the abdominal fat distribution except for that in group $\mathrm{C}(\mathrm{r}=0.77$, $\mathrm{p}<0.05)$.

\section{Discussion}

The present results indicated that the abdominal fat distribution of regular exercisers is smaller than that of non-regular exercisers; in particular runners' visceral fat amount was significantly less than those of swimmers and the control groups. However, the contribution of abdominal fat to serum leptin levels could not be definitely concluded due to the diverse relationships between the abdominal fat distribution and leptin levels in exercisers. In addition, even in regular exercisers with lower abdominal fat volumes, waist circumferences were related to abdominal fat.

\section{Abdominal Fat Distribution in Regular Exercisers}

In comparison to BMI-matched controls and even with no significant difference in the percent body fat according to the statistical analysis, regular exercisers demonstrated smaller abdominal visceral fat volumes (56\% less for runners and 11\% less for swimmers) compared to controls. Many studies (Nagura et al. 2004; Meriño-Ibarra et al. 2005; Tarui, Tokunaga, Fujioka, and Matsuzawa, 1991) showed that abdominal visceral fat accumulation plays a key role in the development of cardiovascular diseases and metabolic syndrome, although 
the definitive mechanisms between abdominal visceral fat accumulation and these cardiometabolic diseases are not clearly established. However, the productions of several molecules such as tumor necrosis factor, resistin, plasminogen activator inhibitor 1, and interleukin (IL)6, which are likely associated with these kinds of diseases (Erin and Flier, 2004), were attributed to an accumulation of intra-abdominal visceral fat. As a result, the suppression of visceral fat accumulation should be highlighted. On the other hand, there was no significant difference in abdominal subcutaneous fat volume, although the swimmers' amount was the highest among these three groups. This is possibly because swimmers are accustomed to an exercise environment with a lower temperature. Many studies have reported that regular exercise benefits body health, such as decreasing body fat and changing blood lipids. In addition, ex-exercisers and athletes who gain weight increase their risk of cardiovascular diseases when they discontinue exercise (Pihl and Jürimäe, 2001). As a result, maintaining regular exercise will help inhibit the accumulation of abdominal fat and decrease the risks of associated diseases.

\section{Abdominal Fat Distribution and Serum Leptin Levels}

The result of leptin being significantly relating to the percent body fat is in agreement with other studies that examined different athletes (Hickey et al., 1996; LealCerro et al., 1998, Noland et al., 2001). Results showed that body fat also plays an important role in the leptin production of exercisers. However, relationships between serum leptin levels and the abdominal fat distribution are diverse in exercisers engaged in different sports. In this regard, the result for group $\mathrm{R}$ differed from that of group $\mathrm{C}$ in the current study and another study (Banerji, Faridi, Atluri, Chaiken, \& Lebovitz, 1999), which showed no significant relationship between abdominal visceral fat and serum leptin levels. There are two possible reasons for this difference. First, people engaging in regular exercise or training undergo greater lipolysis because of stimulation by adrenalin. Intra-abdominal adipose tissue is more sensitive to adrenalin (Alvarez, Ballard, Beske, \& Davy, 2004; Enevoldsen et al., 2001). A second reason is blood flow. Bülow and Tøndevold (1982) reported that blood flow was elevated to 2.5 3-fold in perirenal, mesenteric, and pericardial tissues due to exercise. We speculated that adrenaline in the presence of greater blood flow from frequent exercise stimulation in regular runners might cause higher lipolysis and substance production in adipose fat tissues and this was possibly closely related to leptin.
The relationship between abdominal subcutaneous fat and serum leptin levels in the control group was similar to results of other studies (Fisher et al., 1999; Tai, Lau, Ho, Fok, \& Tan, 2000). However, different results were also shown between the $\mathrm{R}$ and $\mathrm{S}$ groups. One possible reason is that individual gene expressions differ due to different extents of adipose tissue (Masuzaki et al., 1995). Accordingly, although we found that the contribution of body fat to leptin in exercisers was similar to results of other studies (Hickey et al., 1996; Leal-Cerro et al., 1998, Noland et al., 2001), to what extent leptin is influenced by abdominal fat or what a role abdominal fat plays in leptin production could not be determined in the current study. Further research is needed to examine relationships of the abdominal fat distribution with serum leptin levels in athletes and regular exercisers.

\section{Waist and Hip Circumference along with Abdominal Fat Distribution}

In the general population, many studies suggested that such easy-to-measure body parameters as WC, HC, waist-to-hip ratio (WHR), and BMI can be related to the abdominal fat distribution, and a predictive formula for the abdominal fat distribution was even developed (Clasey et al., 1999; Pouliot et al., 1994;). This is one of the few studies to try to discuss this issue in exercisers. In this study, WC was also an anthropometric index used to correlate the abdominal subcutaneous fat of regular exercisers. From the preliminary results, it was similar in non-exercisers and non-athletes. However, relationships of the WC with abdominal visceral fat in group $\mathrm{S}$ and of the $\mathrm{HC}$ with abdominal subcutaneous fat in the $\mathrm{R}$ and $\mathrm{S}$ groups were not strong enough to be statistically significant. Therefore, the result that the WC is superior to the $\mathrm{HC}$ in its relationship with the abdominal fat distribution in exercisers was the same as found in studies by Chan et al. (2003) and Roopakala et al. (2009), which examined non-exercisers. Additionally, a predictive formula for athletes and exercisers' abdominal subcutaneous fat can be developed if more of these kinds of participants are included in the future. With respect to whether $\mathrm{HC}$ can be regarded as an index for the abdominal fat distribution in athletes or exercisers, it is difficult to reach such a conclusion according to these primary results. 


\section{Limitations}

There are many factors that influence the distribution of body fat, including diet, gene, culture, and genders. The current study failed to investigate and trace back the diet record of subjects over a period of time. However, all participants provided at least 3 years of health check records, and we found that there were no significant differences in their weights after analysis (data not shown). This might indirectly indicate good maintenance of dietary habit.

In summary, results of the present study show that the exercise groups ( $\mathrm{R}$ and $\mathrm{S}$ groups) had less abdominal visceral fat than the $\mathrm{C}$ group. This suggests that regular exercise may reduce disease risks from the accumulation of abdominal visceral fat. In terms of body circumferences and abdominal fat distribution, the WC was also determined to be an anthropometric index for abdominal subcutaneous fat of regular exercisers. On the other hand, because relationships between serum leptin levels and abdominal fat distribution in regular exercisers who engage in different sports differ, further studies, which examine the expression of the ob gene in different abdominal fat parts and blood distribution are needed for exercisers and athletes.

\section{References}

Alvarez, G. E., Ballard, T. P., Beske, S. D., \& Davy, K. P. (2004). Subcutaneous obesity is not associated with sympathetic neural activation. American Journal of Physiology. Heart and Circulatory Physiology, 287, H414-H418.

American College of Sports Medicine. (2006). ACSM's Guidelines for Exercise Testing and Prescription ( $7^{\text {th }}$ edition). Baltimore, MD: Lippincott Williams \& Wilkins.

Banerji, M. A., Faridi, N., Atluri, R., Chaiken, R. L., \& Lebovitz, H. E. (1999) Body composition, visceral fat, leptin, and insulin resistance in Asian Indian men. The Journal of Clinical Endocrinology and Metabolism, 84, 137-144.

Berggren, J. R., Hulver, M. W., \& Houmard, J. A. (2005). Fat as an endocrine organ: Influence of exercise. Journal of Applied Physiology, 99, 757-764.
Borg, G. (1998). Borg's Perceived Exertion and Pains Scales. Champaign, IL: Human Kinetics.

Bülow, J., \& Tondevold, E. (1982). Blood flow in different adipose tissue depots during prolonged exercise in dogs. Pflügers Archiv : European journal of physiology, 392, 235-238.

Campfield, L. A., Smith, F. J., Guisez, Y., Devos, R., \& Burn, P. (1995). Recombinant mouse OB protein: evidence for a peripheral signal linking adiposity and central neural networks. Science. 269, 547-549.

Chan, D. C., Watts, G. F., Barrett, P. H., \& Burke, V. (2003). Waist circumference, waist-to-hip ratio and body mass index as predictors of adipose tissue compartments in men. Quarterly Journal Medicine, 96(6), 441-447.

Clasey, J. L., Bouchard, C., Teates, C. D., Riblett, J. E., Thorner, M. O., Hartman, M. L., \& Weltman, A. (1999). The use of anthropometric and dual-energy $\mathrm{X}$-ray absorptiometry (DXA) measures to estimate total abdominal and abdominal visceral fat in men and women. Obesity Research, 7(3), 256-264.

Considine, R. V., Sinha, M. K., Heiman, M. L., Kriauciunas, A., Stephens, T. W., \& Nyce, M. R., et al. (1996). Serum immunoreactive leptin concentration in normal weight and obese humans. New England Journal of Medicine, 334, 292-295.

Durnin, J. V., \& Womersley, J. (1974). Body fat assessed for total body density and its estimation for skinfold thickness: measurement in 482 men and women aged from 16 to 72 years. British Journal of Nutrition, 32(1),77-97.

Enevoldsen, L. H., Stallknecht, B., Langfort, J., Petersen, L. N., Holm, C., \& Ploug, T., et al. (2001). The effect of exercise training on hormone-sensitive lipase in rat intra-abdominal adipose tissue and muscle. Journal of Physiology, 536, 871-877.

Erin, E. K., \& Flier, J. S. (2004). Adipose tissue as an endocrine organ. Journal of Clinical Endocrinology and Metabolism, 89, 2548-5256. 
Fisher, J. S., Hickner, R. C., Racette, S. B., Binder, E. F., Landt, M., \& Kohrt, W. M. (1999). Leptin response to insulin in humans is related to the lipolytic state of abdominal subcutaneous fat. Journal of Clinical Endocrinology and Metabolism, 84, 3726-3731.

Halaas, J. L., Gajiwala, K., Maffei, S. M., Cohen, S. L., Chait, B. T., \& Rabinowitz, D., et al. (1995). Weight-reducing effects of the plasma protein encoded by the obese gene. Science, 269, 543-546.

Haskell, W. L., Lee, I. M., Pate, R. R., Powell, K. E., Blair, S. N., \& Franklin, B. A., et al. (2007). Physical activity and public health: updated recommendation for adults from the American College of Sports Medicine and the American Heart Association. Medicine and Science in Sports and Exercise, 39(8), 1423-1434.

Hickey, M. S., Considine, R. V., Israel, R. G., Mahar, T. L., McCammon, M. R., \& Tyndall, G. L., et al. (1996). Leptin is related to body content in male distance runners. American Journal of Physiology, 271, E938E940.

Kim, S. K. J., Kim, H. J., Hur, K. Y., Choi, S. H., Ahn, C. W., \& Lim, S. K., et al. (2004). Visceral fat thickness measured by ultrasonography can estimate not only visceral obesity but also risks of cardiovascular and metabolic diseases. American Journal of Clinical Nutrition, 79, 593-599.

Leal-Cerro, A., Garcia-Luna, P. P., Astorga, R., Parjeo, J., \& Peino, R., et al. (1998). Serum leptin levels in male marathon athletes before and after the marathon run. Journal of Clinical Endocrinology and Metabolism, 83, 2376-2379.

Masuzaki, H., Ogawa, Y. Isse, N., Satoh, N., Okazaki, T., \& Shigemoto, M., et al. (1995). Human obese gene expression. Adipocyte-specific expression and regional differences in the adipose tissue. Diabete, 44, 855858.

Meriño-Ibarra, E., Artieda, M., Cenarro, A., Goicoechea, J., Calvo, L., \& Guallar, A., et al. (2005). Ultrasonography for the evaluation of visceral fat and the metabolic syndrome. Metabolism, 54, 1230-1235.
Nagura, J., Y. Nakagawa, M. Miyanaga, Matsuoka, K., Hayashi, K., \& Ozasa, K., et al. (2004). Relationship between abdominal visceral fat and lacunar infarcts in Japanese Men. Circulation Journal, 68, 982-987.

Noland, R. C., Baker, J. T., Boudreau, S. R., Kobe, R. W., Tanner, C. J., \& Hickner, R. C., et al. (2001). Effect of intense training on plasma leptin in male and female swimmers. Medicine and Science in Sports and Exercise, 33, 227-231.

Pelleymounter, M. A., M. J. Cullen, M. B. Baker, Hecht, R., Winters, D., \& Boone, T., et al. (1995). Effects of the obese gene product on body weight regulation in ob/ob mice. Science, 269, 540-543.

Pratley, R. E., Hagberg, J. M., Rogus, E. M., \& Goldberg, A. P. (1995). Enhanced insulin sensitivity and lower waist-to-hip ratio in master athletes. American Journal of Physiology, $268(3 \mathrm{Pt}$ 1), E484E490.

Pihl, E., \& Jürimäe., T. (2001). Relationships between body weight change and cardiovascular disease risk factors in male former athletes. International Journal of Obesity and Related Metabolic Disorders, 25, 1057-1062.

Pouliot, M., Despres, J-P., Lemieux, S., Moorjani, Bouchard, S. C., \& Tremblay, A. (1994). Waist circumference and abdominal sagittal diameter: best simple anthropometric indexes of abdominal visceral adipose tissue accumulation and related cardiovascular risk in men and women. American Journal of Cardiology, 73, 460-468.

Ronnemaa, T., Karonen, S., Rissanen, A., Koskenvuo, M., \& Koivisto, V. A. (1996). Relation between plasma leptin levels and measures of body fat in identical twins discordant for obesity. Annals of Internal Medicine, 126, 26-31.

Roopakala, M. S., Suresh, A., Ashtalakshmi, Srinath, Ashok, Giridhar, Anand, \& Silvia W. D. (2009). Anthropometric measurements as predictors of intraabdominal fat thickness. Indian Journal of Physiology and Pharmacology, 53(3), 259-264. 
Ross, R., Shaw, Rissanen, K., Martel, J. Y., Guise, J., \& Avruch, L. (1994). Sex difference in lean and adipose tissue distribution by magnetic resonance imaging: anthropometric relationships. American Journal of Clinical Nutrition, 59, 1277-1285.

Siri, W. E. (1961). Body composition from fluid spaces and density: analysis of methods. In Brozeck, J. \& Henschel, A. (Eds.), Techniques for Measuring Body Composition (pp.223-244). Washington, DC: National Academy of Sciences, National Resource Council.

Sugawara, J., Miyachi, M., Moreau, K. L., Dinenno, F. A., Desouza, C. A., \& Tanaka, H. (2002). Agerelated reductions in appendicular skeletal muscle mass: association with habitual aerobic exercise status. Clinical Physiology and Functional Imaging, 22(3), 169-172.
Tai, E. S., Lau, T. N., Ho, S. C., Fok, A. C., \& Tan, C. E. (2000). Body fat distribution and cardiovascular risk in normal weight women. Associations with insulin resistance, lipids and plasma leptin. International Journal of Obesity and Related Metabolic Disorders, 24, 751-757.

Tarui, S., Tokunaga, K., Fujioka, S., \& Matsuzawa, Y. (1991). Visceral fat obesity: anthropological and pathophysiological aspects. International Journal of Obesity, 15, 1-8.

\section{Correspondence:}

Te Hung Tsao

Division of Physical, Health and Service Learning Center, National Sun Yat-sen University

Telephone: 886-7-7266553

E-mail address: t1208t2001@gmail.com 